\title{
The Effect of Project Implementation on Poverty Reduction in Rwanda: A Case Study of Project in Vision 2020 Umurenge Programme in Bugesera District- Rwanda
}

\author{
Nabalinda Chantal* \\ Dr. Bogere Muhamad, PhD** \\ * MBA student, Mount Kenya University, Rwanda \\ **Senior Lecturer, Mount Kenya University, Rwanda \\ DOI: 10.29322/IJSRP.10.09.2020.p10598 \\ http://dx.doi.org/10.29322/IJSRP.10.09.2020.p10598
}

\begin{abstract}
The main objective of the study was to investigate the effect of project implementation on poverty reduction especially those projects in VUP. The researcher adopted the descriptive survey design because the study sought to gain insight or perception into a phenomenon as a way of providing basic information in the area of study. The study population comprised 1481 in total including 1361 VUP Beneficiaries, 15 Executive Secretaries of sector and 105 Executive Secretaries of cells in Bugesera District. The researcher used simple randomly sampling to select the sectors and used also purposive sampling to select the cells. The researcher used Morgan and Robert formula to determine the sample size. Primary data was collected using the questionnaire and interview. The interview was used for executive secretaries of cells and sectors and questionnaires for VUP beneficiaries. Data was analysed into tables and graphs applying descriptive statistics (frequency, percentages and mean) by statistical tools such STATA 13.1. The research revealed that VUP project are interested according to objective one the majority $(96.07 \%)$ of respondent agreed to the statement saying that public work on poverty reduction is highly appreciated. Due to the objective two also, the respondent highly appreciated at $89.27 \%$ of the respondents and they confirm that direct support on income generation for beneficiaries toward poverty reduction is needed for different beneficiaries. The findings have key policy implications calling upon the government and policy makers to focus not only on the development of social services but also on the development of agriculture and other small business enterprise.
\end{abstract}

Key Words: VUP Programme, Poverty reduction, Direct support, Credit package, Rwanda

\subsection{Introduction}

There has been much efforts world over to reduce extreme poverty levels in most counties. These efforts have not only

This publication is licensed under Creative Commons Attribution CC BY.

http://dx.doi.org/10.29322/IJSRP.10.09.2020.p10598 been carried out by international organizations, but also by different governments across the globe. However, poverty still remains a great challenge especially for developing nations and more a challenge for Least Developed Countries (LDCs). In these countries more than $75 \%$ of the population are still in extreme poverty (United Nations Conference on Trade and Development UNCTAD, 2019). According to a report jointly prepared by United Nations Department of Economic and Social Affairs (UN DESA) and other United Nations bodies, many countries still drag in the fight to reduce poverty levels. The report highlights challenges that are faced by these nations in regard to poverty and the related problems. The report further mentions that one of the key efforts for poverty eradication is for countries to achieve Sustainable Development Goals (SDGs) which should be a collaborated effort of the national governments, international bodies and the private sector (DESA UN, 2020). Therefore, poverty and hunger reduction in both rural and urban areas, will depend on the sustainability of community development.

Nowadays many people are worried about the growth concept for many reasons a realization which is not better, and/or devising strategies to reduce outside dependencies and minimizing the level of poverty. The development of the community takes into account the conditions and the contribution of the community. With the development of the community, the intention is to improve the quality of life. This development of community is not achieved by an individual alone but it is achieved through mutual responsibilities. The development should recognize social, cultural, economic and environmental conditions.

Rwanda started applying the new strategy to eradicate poverty in 2008. That development is called Economic Development and Poverty Reduction Strategy (EDPRS). Since 2008-2012, EDPRS sets the objectives of priorities to be achieve in next five years in three programs such as: increase of jobs, governance and vision 2020. The country level stakeholders support the program of EDPRS. As the government of Rwanda created 
different programs to fight against poverty vision 2020 is the first, EDPRS is the second. All these programs facilitate the achievement of MDGs which lead to the sustainable development (Economic Development and Poverty Reduction Strategy, 2007).

The research in Rwanda shows that the poverty of citizens has root from the destruction of properties as the consequences of 1994 genocide against Tutsi, shortage of land, environmental degradation, etc. Poverty is the problem that goes beyond lack of food, clothes, shelter and social welfare (Bugingo, 2001). In general, development in Rwanda for eradicating poverty is guided under 2020 vision for the development of Rwanda, it presents the key priorities and provides development of Rwanda with the guidance to the future's economic development and poverty reduction strategy to eradicate the barriers for millennium development goals and the country's vision 2020. In fact, "the Vision 2020 Umurenge Program (VUP) has been implemented in Bugesera district to improve living conditions of the population. The researcher investigated the impact of VUP project implementation on poverty reduction to improve the living conditions of the beneficiaries.

Reducing poverty has been a great matter of concern to Rwanda due to the fact of what happened in 1994 of the Genocide against Tutsi. Many infrastructures were destroyed which left the people in rural areas with scarce resources and insecure with housing, food and shelter problems. However, to build successful local rural areas through VUP contribution for accelerated poverty reduction and development in economic growth, agricultural inputs resources on making agricultural growth performance must be available to policy makers (PRSP, 2011).

The people of the Bugesera District still practice poor and/or traditional ways of doing agriculture in their livelihood, where the majority of Bugesera District specifically those of Ngeruka Sector, Rweru Sector, Mwogo Sector, Nyarugenge Sector and Shyara Sector live under poverty line within limited plots. Their capacity was very limited to boost their agricultural practice and production, they depend mainly on agriculture for surviving and remain as the most vulnerable and marginalized people in Rwanda. Progress in poverty reduction and speed economic development, Rwanda is still facing many developmental challenges. The most recent household living conditions survey (the EICV 4) also found that poverty rates vary enormously between provinces and from district to district (Bugingo, 2001).

Poverty is still a big problem in rural compared to the urban area whereby $48.7 \%$ in rural area fall under the line of poverty while only $22.1 \%$ in urban area fall under the line of poverty. There is also a big challenge in accessing social amenities and social facilities. EICV 4 shows that Bugesera district ranks $9^{\text {th }}$ among the districts whose population fall in the category of poor population. This category represents $47.7 \%$ of the population in Bugesera, making up about 173,313 persons. Just over half $(52.3 \%)$ of the population in Bugesera district is identified as non-poor, $34.3 \%$ as poor (excluding extremepoor) and $13.4 \%$ as extreme-poor. While compared with other seven districts of Eastern Province, Bugesera District is ranked third by levels of non-poor after Rwamagana and Kayonza districts (National Institute of Statistics, 2013).

The general objective of the study was to establish Impact of project implementation on poverty reduction to promote the living condition of people in Bugesera District, Rwanda. The specific objectives that guided this research were

i. To identify the roles of public work on poverty reduction in Bugesera District, Rwanda.

ii. To assess a direct support on income generation for beneficiaries toward poverty reduction in Bugesera District, Rwanda.

iii. To examine the potential capacity of financial services to eradicate the poverty in Bugesera District, Rwanda.

\section{LITERATURE REVIEW}

\subsection{Theoretical Literature}

Poverty is the state in which individuals lack what they need for surviving for example, food, house, clothes, poor water and other facilities (Sen, 1999). If poverty undermines the welfare of people, it should not be seen and keep quiet instead everyone should work hard and be innovative as well as creative to initiate the income generating activities and be responsible for their lives (Goetz, 2003; Goering, Feins, and Richardson, 2003).

On the other hand, if traditionally, some people believe that poverty is hereditary, the government should not keep quiet instead should educate them about the cause of poverty and how to fight against it. Another problem is trying to work traditionally based on the culture for example sticking on agriculture for only consumption, and not participating in international trade therefore the government should sensitize people about the strategies of raising family economy that goes beyond family consumption and think about money provision. Many literatures show that many people fall under the line of poverty without considering how much competent they may be. The problem of poverty is that the families are not satisfied in their needs (Jencks, 2011). Poverty is seen as the results of unemployment or nonproductive jobs.

Rwandan government knows that its institutions apply primordial inspiration on the stability of the society, wealth and the welfare of its populations. The stability of economy of the government depends upon the well-functioning of government entities, civil societies and non-governmental organizations. This way the government of Rwanda tries to enhance the good governance first for sustainable development because without good governance nothing can go smoothly in the country. Today's hindrances of social and economic development in Rwanda are in these categories. The rampage problem of poverty from generations to others. The problems caused by the genocide of 1994 against Tutsi as its consequences such as destruction of infrastructure and loss of properties. Nowadays the government of Rwanda is dealing with the issue of strengthening the power of populations so as to help them come from the line of poverty and achieve the line of wealth these are being done through different programs like EDPRS and VUP (Bugingo, 2001). 


\subsection{Empirical Review}

This is our aspiration as Rwandans to build the government of national unity which is democratic and which ensures the sustainable development of the country. The Rwandan government strives to be successful at both regionally and internationally (Vision 2020, 2000). For attaining this, 2020 vision outlines six intermingling pillars, comprising governance and well-organized State, expert and capable human capital, private sector which are vibrant, in addition to sophisticated agriculture and modern livestock 2020 vision is the results of the national consultative held from 1997-2000.

This negotiation included different citizens of Rwanda from different domains, such as civil society, political leaders, members of different political leaders and other consultative (vision 2020, 2000). Community works are used as the strategies to enhance community assets without spending a lot of money. As we have private land ownership is in Rwanda, the public works are mostly done on the land belongs to the government. The community work should benefit the whole society without discrimination.

The government should set the strategies to eradicate poverty. These strategies include the well use of scarce resources and work hard to increase the available resources. Therefore, the government should high the manpower who are able to use and train others to use resources well, and who can encourage creativity among people.

EDPRS is considered as a process and as well as document. First of all EDPRSS outlines, the objectives and the policies for the country development (2008-2012). It provides a map of government, the partners and the private sectors. It shows where the government of Rwanda wants to achieve and the needs for achieving there.

The EDPRS is broken into 2 (two) ways. At the first the strategies redefine the country's economy. At second, the strategies explain the ways in which we can do things in Rwanda. Particularly the case for consolidating and extending of decentralization of public. The also considered the role of private sector in growth acceleration in order to reduce poverty (EDPRS, 2007).

The EDPRS allocates the necessity for accelerating the growth to make employment and increase exports. This will be achieved through ambitions, the quality of the public investment program and this aimed to reduce the price of business. This will create the strong incentives for private sectors so as to improve its investment in the coming years. With $2 / 3$ of the population aged below 25 (twenty-five) years. Mainly the emphasis was on creating opportunities for young population.

2020 vision Umurenge is a decentralized and integrated rural development program intended to make poverty reduction acceleration in Rwanda. This was recently tried in the thirty sectors of the country. The 2020 vision Umurenge program (VUP) utilizes present system of decentralization and influences monetary and technical assistance to accelerate the level of reduction of poverty. The target is to eradicate the dangerous poverty.

\subsection{Theoretical Framework}

VUP's theories presents the overall goal of the programme, that is, to contribute to reduced income poverty and inequality levels in Rwanda. It also presents the programmer's purpose which is to quicken the poverty reduction levels in targeted VUP sectors. As previously noted, the framework is based on the theory of change of VUP that uses programme components to support people living in extreme poverty in order for them to eventually graduate out of poverty, thus reducing the overall extreme poverty level in the country.

However, specific outcomes, or results for each programme and operational component could be elaborated to allow for evaluation at a level higher than outputs and to better consider the overall desired impact of each component and area of VUP. Further, the framework with 2009/2010 progress does not include performance data for some of the key outputs, in particular due to an unavailability of information not only at National level, even for the region level.

The output level of the VUP's theories framework is well formulated and the indicators developed provide adequate measurement for quantitative information. More qualitative information about programme delivery and effectiveness is needed and indicators should be reflecting both annual and end-line targets. Further, a risk analysis and inclusion of key assumptions should be conducted in order to mitigate potential risks (World Bank, 2003).

Although some of the outputs can be achieved, the VUP framework does not clearly link this with addressing the causes of poverty. In particular, problems such as mindset, capacity building and training, sensitization, participation and ownership, collaboration between actors and interface management are not explicitly expressed in the VUP framework. This can hamper sustainability of VUP's achievements. There should be a consideration of the causes of poverty within VUP communities such as low capacity of beneficiaries, financial illiteracy and cultural hindrances (such as the perception that taking credit is a sign of economic weakness, or the economic exclusion of women, etc). Although this has been discussed elsewhere, some of these causes and challenges was more explicitly elaborated in the logical framework.

The framework was also need to consider the sustainability of outcomes. In particular, how to make sure that the achievements will continue to manifest themselves over a long period of time without VUP. This was considered VUP's exit strategy, which is lacking from the program altogether. Without a sustainable exit strategy, VUP achievements could be severely threatened.

\subsection{Conceptual framework}

This links the variables in the study at abstract level. The "conceptual framework" is a graphic presentation of the interrelationships of the variables at play Newton (2001). The following conceptual framework illustrates different variables involved in this study. 
Independent Variable: VUP Project Implementation

Public work: money to help poor families.

$>$ Direct Support: transfer of money to the poorest families.

$>$ Financial Services: Facilitates the providing of finance and prepare training for poor.
Dependent Variable:

Poverty Reduction

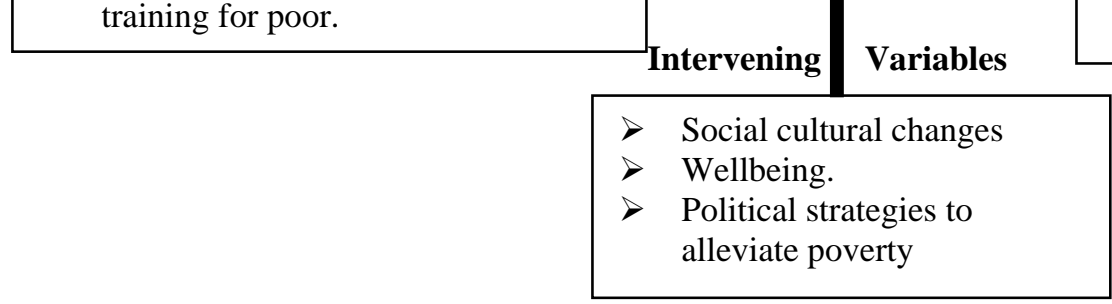

Figure 1: Conceptual Framework

Source: Researcher, 2020

The figure shows the three main components of the project where VUP aims to see beneficiaries move from category 1 and 2 of ubudehe to higher categories, demonstrating a decrease in poverty levels. The three components' programme are not automatically reciprocally exclusive. For example public works can be complemented with credit packages through financial services (FS). One of the purposes of FS is to allow participants to develop their own projects that will eventually be self-sustainable and enable them to graduate out of extreme poverty. Although participants could be engaged in FS and PW or DS, they are only able to be engaged in PW or DS, not both at the same time.

Each component is analyzed separately to allow for an understanding of the most effective programme component to the graduation of beneficiaries. In addition, VUP makes a distinction among household and household members. Eligibility depends on household membership, rather than being the head of household. This is important in order to fitin the females and young who present the main productive capacities but may not be the head of families. The components of the programme should be implemented in the project, which are intended and coordinated at Umurenge level and put into practice at village level. All components and program of the project linked to specialists at the level of the sector who gives the strategic orientations, in addition to basic technical standards and policies.

\section{RESEARCH METHODOLOGY}

\subsection{Research design and Population}

Mitchell and Jolley (2012) recommended the descriptive survey design for the study whereby behaviors, thoughts, opinions and comments on the issues under investigation. In this present study the descriptive survey was chosen due to the objectives of the study. The study population comprised 1481 in total including 105 Executive Secretaries (E.S) Cell, 15 E.S Sector and 1361 VUP beneficiaries means each sector provided about 90 VUP beneficiaries.

\subsection{Sample design}

The researcher chose the zone purposively and used simple randomly sampling to select the sectors in Bugesera District; the technique that was used to select the cell implementing the VUP program is called simple stratified. Stratified sampling gave all cells equal chance to participate in the study.

According to Mugenda (2008), at least 11 percent the population is enough for descriptive survey study. Representatives of E.S cells of selected cells was purposively selected to yield 105E.S cells. This technique of sampling was used by the researcher based on the experience, qualities, knowledge of the all executive secretary to provide virtue information. The purposive sampling or judgment sampling technique is the deliberate choices of researcher due to the qualities the respondents possess (Bernard, 2002). Executive secretaries' representatives regularly participate in the VUP planning and management and that issue of poverty reduction. They will be often used by the researcher to deal with and handle different issues of poverty reduction through VUP components raised in the district.

Purposive sampling technique was used to select sector where the VUP is implemented such Ngeruka Sector, Kamabuye Sector and Rweru Sector from all sectors in Bugesera District. The number respondents were sampled using the Robert and Morgan (1970) technique which employs the Robert and Morgan's table that is generated from the sampling formula:

$$
n=\frac{\chi^{2} N P(1-P)}{d^{2}(N-1)+\chi^{2} P(1-P)}=\frac{3.841 * 1481 * 0.5 * 0.5}{0.05^{2} * 1480+3.841 * 0.5 * 0.5} \approx 305
$$

$\mathrm{n}=$ sample size that is necessary

$\chi^{2}=$ the table value of chi-square for 1 degree of freedom at the desired confidence level (3.841).

$\mathrm{N}=$ the population size.

$\mathrm{P}=$ the population proportion (assumed to be 0.50 since this would provide the maximum Sample size).

$\mathrm{d}=$ the degree of accuracy expressed as a proportion (0.05). 
Table 1: Targeted population and sample size

\begin{tabular}{lcc}
$\begin{array}{l}\text { Group of } \\
\text { Respondents }\end{array}$ & Targeted Population & Sample Size \\
\hline E.S Sectors & 15 & 3 \\
E.S Cells & 105 & 21 \\
VUP Beneficiaries & 1361 & 281 \\
TOTAL & $\mathbf{1 4 8 1}$ & $\mathbf{3 0 5}$ \\
\hline
\end{tabular}

Source: Researcher, 2019

\subsection{Data Collection and Analysis}

Data collection method is the systematic and exact method of collecting the relevant information comparing to the purpose of the study, to address the objectives of the study, and research questions or hypotheses (Burns \& Grove, 1993). The researcher used the combined method that consisted of structured questionnaire and interview. Majority were not able to read and interpret items on questionnaire which were set in English. The researcher therefore translated English into Kinyarwanda to make them understand clearly every item on the questionnaire for VUP beneficiaries. Another way used to get data from the executive secretaries is interview (E.S) because their number is limited.

These structured questionnaires were administered to this category of respondents whose views, opinions and attitudes on how the VUP components affect the poverty reduction to promote the living condition of poorest people in Bugesera district (Kothari, 2004). The questionnaire is also appreciated as Table 2: Gender of the Respondents

\begin{tabular}{llllll}
\hline Gender & VUP Beneficiaries & E.S Sector & E.S Cells & Total & Percentage \\
\hline Male & 124 & 3 & 14 & 141 & 46.22 \\
Female & 157 & 0 & 7 & 164 & 53.78 \\
\hline
\end{tabular}

As shown in Table 2 the respondents to the side of respondents were given equal chance and the male were 141 of 305 equals $46.22 \%$ while female respondents were 164 of 305 equals to $53.78 \%$. This means that the gender was ensured by the researcher during the "research."

\section{VUP Beneficiary Categories}

All VUP beneficiaries are involved in the study, the selection was based on the knowledge, their motivation for VUP activities and period working with the Vision 2020 Umurenge Programme. There are 4 categories of VUP Beneficiaries like "Absolutely poorer (Umutindi nyakujya), Very Poor (Umutindi), Poor (Umukene), Resourceful poor (Umukene wifashije". The study set to gather information on the categories of VUP Beneficiaries of participants. The outcomes are recorded in Figure 2.

As shown in Figure 2, those who were classified as absolutely poor were 107 , those very poor were 103 while 42 were poor and 25 resourceful poor. using statistical tools like Stata 13.1 Beneficiaries. it was easily used on a large number of subjects. The questionnaire has composed of closed-ended questions. Likert Scale questions was used to measure extent of agreement or disagreement of respondent according the statement. The questionnaires were individually administered by the researcher and directed to the participants.

The semi-structured interview schedules were considered appropriate to the local authorities. Therefore, it was used to obtain the supplementing information from the local authorities. The purpose of interview was to elicit information that supplemented the data to be gathered through questionnaires.

Quantitative data from the questionnaires was examined by descriptive statistics which include frequencies, percentages by

\section{RESEARCH FINDINGS AND DISCUSSIONS}

The findings from the study established that 100\% VUP Beneficiaries of questionnaires were returned. The researcher managed to interview 3 E.S Sector and 21 E.S Cells interviewed in the selected sectors and cells.

\subsection{Demographic characteristics of respondents}

The section shows the background of the respondents according to their categories such as age, education level, family status, gender. The total number of the respondents was 305 and they were made of 3 E.S Sector, 21 E.S Cells and 281 VUP

Table 4.1 represented the spreading of 281 VUP beneficiaries and 3 E.S Sector and 21 E.S Cells provided to them by their sex. 
population has past more than one year as VUP beneficiaries.

Table 3: The responses from respondent on objective 1

\begin{tabular}{|c|c|c|c|c|c|c|c|c|c|c|}
\hline \multirow[t]{2}{*}{ Statement } & \multicolumn{2}{|c|}{ SD } & \multicolumn{2}{|c|}{ D } & \multicolumn{2}{|c|}{$\mathbf{N}$} & \multicolumn{2}{|c|}{$\mathbf{A}$} & \multicolumn{2}{|c|}{ SA } \\
\hline & freq & $\%$ & freq & $\%$ & freq & $\%$ & freq & $\%$ & freq & $\%$ \\
\hline $\begin{array}{l}\text { The public work fit in the economies } \\
\text { development for beneficiaries }\end{array}$ & 2 & 0.71 & 4 & 1.42 & 5 & 1.77 & 56 & 19.92 & 214 & 76.15 \\
\hline $\begin{array}{l}\text { The public work provide the income } \\
\text { generation toward poverty reduction }\end{array}$ & 3 & 1.06 & 5 & 1.77 & 2 & 0.77 & 112 & 39.85 & 160 & 56.93 \\
\hline $\begin{array}{l}\text { The public work implementation } \\
\text { Participate in poverty reduction }\end{array}$ & 10 & 3.55 & 8 & 2.84 & 4 & 1.42 & 107 & 38.07 & 152 & 54.09 \\
\hline
\end{tabular}

\section{Source: field research, 2019}

Due to their time spent in VUP activities the majority (83\%) indicated the clear roles of public work for their condition of living and they increased the income individually especially payments of mutual de santé, meals number and components increase, saving on account in Umurenge SACCO, payment of school fees for their children

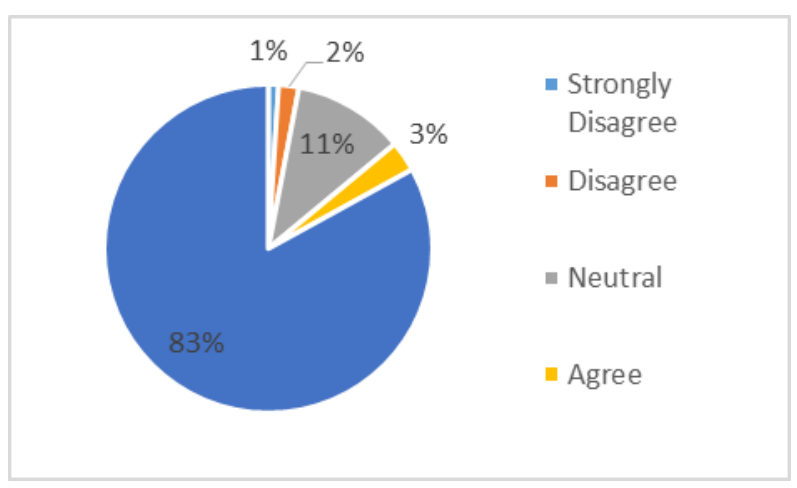

Figure 2: the roles of public work on VUP Beneficiaries Source: field research, 2019

\subsubsection{Impact of Direct support on VUP Beneficiaries for reduction of poverty}

The objective two was to determine the outcome of direct support on income generation for beneficiaries toward poverty reduction, the majority $(85.57 \%)$ respondents strongly agreed with the statement on how the direct support provide the income generation toward poverty reduction to the beneficiaries and the $2.62 \%$ disagreed and $1.64 \%$ strongly disagreed with the statement and $1.31 \%$ was neutral to the statement but all respondent clearly stating that the direct support from VUP and the result from the participants are shown in Table 4.

Table 4: Distribution of respondents toward direct support

\begin{tabular}{|l|l|l|l|l|l|l|l|l|l|l|}
\hline Statement & SD & \% & D & \% & N & \% & A & \% & SA & \% \\
\hline $\begin{array}{l}\text { The Direct support fit in the economies development } \\
\text { for beneficiaries }\end{array}$ & 5 & 1.64 & 8 & 2.62 & 4 & 1.31 & 27 & 8.85 & 261 & 85.57 \\
\hline $\begin{array}{l}\text { The direct support provide the income generation } \\
\text { toward poverty reduction }\end{array}$ & 7 & 2.30 & 6 & 1.97 & 0 & 0 & 81 & 26.56 & 211 & 69.18 \\
\hline $\begin{array}{l}\text { The direct support implementation Participate in } \\
\text { poverty reduction }\end{array}$ & 8 & 2.62 & 9 & 2.95 & 2 & 0.66 & 93 & 30.49 & 193 & 63.28 \\
\hline
\end{tabular}

\section{Source: Researcher, 2019}

The sample was distributed among VUP components as follows: 32\% in Financial Services, 37\% of Public Works and 31\% of Direct Support. Figure 3 shows that VUP components were equal distributed from 2015-2017 on averages, which represent long-term cycles of poverty reduction process among them. With the statement mentioned above the direct support provide the changes of income received from VUP activities toward the beneficiaries.

Figure 3: Direct supports as VUP component and their Distribution beneficiaries for poverty reduction

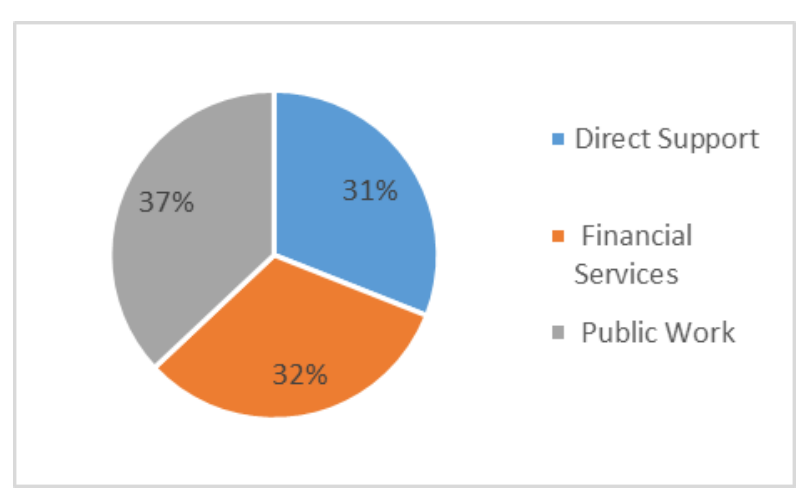

4.2.3 Financial service improves standards of living of Beneficiaries 
The objective three was to examine the potential capacity of financial service to eradicate the poverty and the participants indicated that they were aware of the program and stated they were improved the welfare of their families due to financial services from VUP Programme and through this service they shown the asset gained like Payment of mutuel de Sante , Saving on account in Umurenge Sacco for their economic Table 5: Table Improvement of assets

\begin{tabular}{lll}
\hline No. & Assets gained & Percentage \\
\hline 1 & Payment of mutual de Sante & 89 \\
2 & Meals number and component increase & 81 \\
3 & Saving on account in Umurenge Sacco & 100 \\
4 & School fees payment & 63 \\
5 & Animal husbandry & 51 \\
6 & Land purchase & 19 \\
7 & Family house renovation & 39 \\
8 & New house building & 21 \\
9 & Others( small business , purchase of bicycle & 13 \\
\hline
\end{tabular}

\section{Source: Field research, 2019}

Giving fund to the poorer was suggested as the way to eradicate poverty and increase economic development of the country. Researcher suggested the combination of funding and poverty reduction strategies should be most appropriate. Saving is exhilarated and unpaid, so it is regarded as a private matter, but beneficiary testimonies indicated that people are saving on their accounts. Savings included buying assets, make investments in different resources, paying schools fees of children and having different insurances. development, School fees payment, Family house renovation, Land purchase, New house building, Meals number and component increase, medical healthcare as it is indicated in Table 5 and indicated that the beneficiaries who were categorized as destitute have graduated to the next level of poorest because they have acquired some assets. Data collected present the situation in Table 5.

\subsubsection{Graduation situation of VUP activities within 3 years (2015 - 2017)}

When we talk about graduation of beneficiaries, we are talking about the shift of beneficiaries from one category of poverty to another. As we see, in 2015, we had $5.57 \%$ of beneficiaries which were called "Destitute" but in 2016 we have no "Destitute" in our sample. The poorest were $36.39 \%$ in 2015 but in 2016 there are $28.85 \%$, even if there are $7.54 \%$ who shifted from Destitute to Poorest, the rate remained low because many who were in that category were shifted to another level of Poorer which was 5\% in 2015 but in 2016 it was pushed to $12.20 \%$.

Table 6: Category of poverty

\begin{tabular}{|c|c|c|c|c|c|c|c|c|c|}
\hline Category & Destitute & $\%$ & Poorest & $\%$ & Poorer & $\%$ & Other & $\%$ & Total \\
\hline 2015 & 17 & 5.57 & 111 & 36.39 & 173 & 56.72 & 4 & 1.31 & 305 \\
\hline 2016 & 0 & 0.00 & 88 & 28.85 & 57 & 18.69 & 160 & 52.46 & 305 \\
\hline 2017 & 7 & 2.30 & 90 & 29.51 & 147 & 48.20 & 61 & 20.00 & 305 \\
\hline Total & 25 & & 289 & & 376 & & 225 & & \\
\hline
\end{tabular}

\section{Source-field research, 2019}

It should be noted that because there is no other category to shift to, the category "others" does not change, it remains 61 people because there are Local Leaders, employee in headquarters or in VUP Sector. Overall, VUP's graduation rate is evidence of positive outcomes on poverty alleviation. Furthermore, the presence of cross-cutting issues and outcomes is clearly evident. However, examining VUP at a more granular level indicates some serious shortfalls in outputs. The most drastic of these shortfalls lies in the Financial Services component. VUP has spurred significant poverty reduction in BUGESERA District but hard in extreme poverty matched the average, it lagged in the growth of its Middle Income population.

\subsubsection{Impact of VUP action on beneficiaries toward poverty reduction}

VUP target the poorest people which have nothing to survive and in this research, we found out that VUP has a considerably

Table 7: VUP Impact by Components

\begin{tabular}{llll}
\hline Component & 2015 & 2016 & 2017
\end{tabular}

This publication is licensed under Creative Commons Attribution CC BY.

impact on beneficiaries as we are going to show in following paragraphs. A good number of beneficiaries had acquired a lot of assets such as houses, plots, animal husbandry. All the beneficiaries of VUP have accounts in banks or Umurenge SACCO. To be paid via bank account is very secure that being paid in cash as it reduces the risk of losing the money. VUP also helps the beneficiaries to be familiar with banks and monetary institutions. Moreover, it helps them to save.

\subsubsection{VUP Outputs and Impacts by component}

\subsubsection{Public works}

In 2015, Public works was the operational component, and had more than $47.10 \%$ beneficiary households on different projects.

htp//dx.doior 


\begin{tabular}{|c|c|c|c|c|c|c|}
\hline & Allocation & Execution & Allocation & Execution & Allocation & Execution \\
\hline Public & $43,000,000$ & $31,542,000$ & $148,250,490$ & $147,877,000$ & $105,722,028$ & $92,354,450$ \\
\hline \multicolumn{7}{|l|}{ Works } \\
\hline Direct & $143,000,000$ & $131,542,000$ & $7,218,000$ & $7,334,315$ & $21,280,800$ & $21,061,200$ \\
\hline \multicolumn{7}{|l|}{ Support } \\
\hline Financial & 0 & 0 & $71,020,936$ & $71,020,936$ & $42,334,276$ & $42,333,000$ \\
\hline \multicolumn{7}{|l|}{ Services } \\
\hline Total & $186,000,000$ & $163,084,000$ & $226,489,426$ & $226,231,251$ & $169,337,104$ & $155,748,650$ \\
\hline
\end{tabular}

\section{Source: VUP Data Base VUP Bugeseara 2019}

VUP employed a great number to work on the project of environmental protection were many especially making terraces and fighting against erosion. 59 percent of plans in 2015 to 73 percent in 2015/2017. Another activity in VUP is road making. The activities were diversified over period of time. The new project that was put into practice 2015/2016 were the school construction, markets construction, infrastructure, and increased finance, construction of bridges and cultivation of crops.

During the January-June 2015 mini-budget year, transfers were made of $143,000,000 \mathrm{Rwf}$ to the beneficiaries regarding to the sample size. This was decreased to 7,218,000 Rwf during the $2015 / 2016$ financial year, which also increased to $21,280,800$ Rwf for the financial year 2016/2017, however, as there are families which are poorer, no surprise if they are helped. The poorer families with no capacity to including those in old age, disabled and chronically sick people without forgetting childheaded families. The launch of financial services component was held in January 2015 and VUP, administrative staff at cell and sector levels were trained in Ubudehe Credit Scheme/Financial Service design and procedures.

The first loans were disbursed in March 2016. The form and size of loans given out in fiscal year 2015/2016 where BUGESERA District gained 71,020,936 Rwf. The type of loan given was individual 69 percent and group loan 30 percent and then cooperative loan 1 percent. The total amount of beneficiaries equal to 76 percent. Agriculture, livestock and trade are considered as the basic income generating activities. Other kinds of activities includes non-agricultural trade, hand craft, tailoring and fishing to increase the access to money for poorer families is one of the objectives of VUP. FS programmes are provided mainly to groups rather than individuals, and recipients must present projects to a committee for review, and have a SACCO account. Each sector in a district has an amount of funds to disburse for FS, and sends out a call for proposals. Because the amount given to groups is higher than that for individuals, some form groups to access the higher amount and then fold following the receipt of funds. Initially, the requirement to repay the loan was not very clear to recipients. Many beneficiaries treated the loans as grants. A key challenge in this respect is that VUP staff are also responsible for monitoring loan repayment. Given the wide range of duties of VUP staff, this impacts the efficiency of monitoring. Local authorities, like the SACCOs, do not always feel a sense of ownership towards the VUP FS funding, given its external nature. As a result, they are not sufficiently committed to ensuring its recovery. This, combined with a lack of knowledge (or willingness) among beneficiaries regarding the requirement to repay the loans adds further pressure to the problem of repayment.

\subsection{CONCLUSION AND RECOMMENDATIONS}

As conclusion, this chapter shows that programme of Vision 2020 has actively contributed to the social economic development of its beneficiaries for the purpose of poverty reduction. The programme of VUP has played a vital role in financial transformation, improving standard of living, and easing access to health care through various projects implemented with targeted to eradicate the poverty for the poorest sectors. Government of Rwanda, has played an enormous effort not only to help poor peoples on financial issues but also boost their mind for shifting the agriculture jobs with non-farming jobs. As it was indicated, the big number of respondents have supported the positive change in their socioeconomic development situation after implementation of the program of Ubudehe. This shows a vital role played by the programme of Ubudehe in socio-economic development of its beneficiaries in helping them to cover the basic needs such as health insurance, school attendance, improving their income, savings, standard of living. The programme of Vision 2020 has changed significantly the condition of living of Bugesera District where some residents were hardly paying basic needs such as; medical insurance and materials for children school attendance in basic education and they have arrived at covering some basic needs through income generated by Ubudehe projects.

Having growth of economy, the country should be able to fund the construction of roads and other infrastructures and lead to the opportunities to different trade activities and thereby the reduction of poverty. This intervention should have the ability to foster working productivity growth because better-quality of employees would be more voluntarily offered, while at the same time marketing infrastructure would be improved. In addition, different poverty reduction strategies can be adopted. Analysis should provide clear information on the household, such as the head of the family, the sex of the head, the age of the head, and those who are able to work, those who have daily jobs, the number of hours they work and the amount of money they earn.

Development of economy is necessary but unfortunately there are no enough materials to generate broad strategies for reduction of poverty in Rwanda. Stakeholders and the Rwandan 
ISSN 2250-3153

government should not only focus on the development of social services but also on the development of agriculture and other small business enterprise. The government should also be sure that it has economic integration with other countries so as to make the business easy. The vision 2020 programme is nowadays reliable way for identifying the needs and priorities of the citizens. Therefore, it was the channel the planners have to consider while making the allocation of money in different activities for the communities. The mechanism used to respond to the issues in the communities and the individual poverty is known as VUP. In the expansion of VUP, the focus in the districts should be the poor families, they should be given funds to start small businesses, to be trained on how to start business trained and how to save for the future.

\section{REFERENCES}

[1]. Abayawardana, S., \& Hussain, I. (2002). Water, health and poverty linkages: A Case Study from Sri Lanka. Presented at the Asian Development Bank Regional Consultation Workshop on Water and Poverty, Dhaka.

[2]. Achyut, W. (2008). Human Capital Flight: The Cause of Underdevelopment. Economic Review Occassional Paper, 20.

[3]. Adeyemi, K. . (2012). Sustainable development strategies for poverty alleviation the tax perspectives. In Annual tax conference of the chartered institute of taxation. Nicon Luxury Hotel.

[4]. Baharoglu, D., \& Kessides, C. (2004). Urban

Poverty. In Macroeconomic and sectoral approaches (pp. 124-495). Washington: World Bank.

[5]. Bugingo, E. (2001). Poverty Alleviation and Elimination in Rwanda. Presented at the OSSREA, 2nd National Seminar, Butare: Rwanda Ministry of Education.

[6]. Collier, P. (2007). The Bottom Billion: Why the Poorest Countries Are Failing and What Can Be Done About It. New York, New York 10016: Oxford University Press, Inc. 198 Madison Avenue.

[7]. Desa, U. N. (2020). World Economic Situation and Prospects, 2020. New York: UN DESA.

[8]. Egidijus, B., Rasa, S., Ieva, A., \& Greta, K.-S. (2014). evaluation of social, economic and fiscal impact on incentives of personal taxation in lithuania. Journal of Security and Sustainability Issues, 4(1), 79-95.

[9]. Engvall, A., Sjöberg, Ö. \& Sjöholm, F. (2007). Poverty in Rural Cambodia: The Differentiated Impact of Linkages, Inputs and Access to Land. Research Institute of Industrial Economics, Stockholm.

[10]. Goering, J., Feins, J. D., \& Richardson, T. M. (2003). What have we learned about housing mobility and poverty de-concentration: Choosing a better life? Evaluating the moving to opportunity social experiment, 3-36.

[11]. Goetz, E. G. (2003). Clearing the way: Deconcentrating the poor in urban America. The Urban Insitute.

[12]. ILO. (2004). Decent Work in the Informal Economy in Cambodia: A Literature Review, Informal Economy, Poverty and Employment, . Geneva: International Labour Organisation.
[13]. Kothari, M. (2004). Rural Poverty in Developing Countries: Implications for Public Policy

[14]. Mitchell, M. L., \& Jolley, J. M. (2012). Research design explained. Cengage Learning.

[15]. Mugenda, A. G. (2008). Social science research: Theory and principles. Nairobi. Kijabe printers.

[16]. National Institute of Statistics Rwanda [NISR] (2015). Integrated Household Living Conditions Survey 4th, Social protection and VUP report. Kigali, Rwanda.

[17]. Oseni, M., Ogunlade, O., Oyetunji, O. I. O., \& Sanni, M. R. (2012). Groping In the Dark (Poverty): The Nigerian Experience. European Journal of Humanities and Social Sciences, 17(No. 1).

[18]. Phipps, S. (2003). The Impact of Poverty on Health: A Scan of Research Literature. Canadian Institute for Health Information, Ottawa.

[19]. Quisumbing, A. R., Haddad, L., \& Peña, C. (1995). Gender and Poverty: New Evidence from10 Developing Countries. Washington D.C.: International Food Policy Institute. Simkovic,

[20]. Polit\& Hungler, (1995). Micro finance: A conceptual analysis. Asian Journal of Research in Banking and Finance, 2(12), 44-57.

[21]. Sokha, P. (2005). Decentralization and Poverty Reduction in Cambodia: Experiences and Challenges. In Decentralization: Poverty Reduction, Empowerment and Participation, Division for Public Administration and Development Management (pp. 162-170). New York: United Nations.

[22]. Sullivan, A., \& Sheffrin, S. M. (2003). Economics: Principles in action. Upper Saddle River, New Jersey 07458: Pearson Prentice Hall.

[23]. UNDP. (2000). Responding to Citizens' Needs: Local Governance and Social Services for All (Global Forum on Local Governance and Social Services for All Stockholm). Sweden: United Nations.

[24]. UNPF. (2001). Population, Environment and Poverty Linkages: Operational Challenges (No. 1). New York: United Nations Population Fund.

[25]. World Bank. (2003). World Development Indicators database 2003. Washington D.C.: World Bank.

[26]. World Bank. (2006a). Cambodia: Halving Poverty by 2015? Cambodia World Bank Newsletter.

[27]. World Bank. (2006b). Cambodia: Halving Poverty by 2015? Poverty Assessment 2006. Phnom Penh: World Bank.

[28]. World Bank. (2006c). Governance Indicators for Cambodia 1996-2006. World Bank, Washington.

Nabalinda Chantal (Correspondent Author) MBA student, Mount Kenya University, Rwanda Email:

Dr. Bogere Muhamad, PhD

Senior Lecturer, Mount Kenya University, Rwanda 
International Journal of Scientific and Research Publications, Volume 10, Issue 9, September 2020

ISSN 2250-3153

Email:

This publication is licensed under Creative Commons Attribution CC BY. 